\title{
Summer Drip Irrigation Requirements for Cucumber $^{1}$
}

\author{
Megh R. Goyal and William F. Allison ${ }^{2}$
}

\begin{abstract}
Cucumbers (Variety Poinsett 76) were drip irrigated during March, 1980 at Fortuna Substation to evaluate the water requirement and effect of silver coated plastic mulch on crop performance. The moist treatment gave significant increases in crop yield at the $5 \%$ level compared with wet and dry treatments. The use of plastic mulch further increased production by 4.6 tons per hectare.
\end{abstract}

\section{INTRODUCTION}

Drip irrigation (6) is described as the frequent, slow application of water to soils through mechanical devices called emitters or drippers located at selected points along the water delivery lines. The emitters dissipate the pressure from the distribution system by means of orifices, vortexes, and tortuous or long flow paths. The emitted water moves within the soil system largely by unsaturated flow (6). The drip irrigation is also called trickle-, high frequency-, daily flow-, diurnal-, tension-, capillary-, continuous moisture-, or point source irrigation. There is no difference in the concept these names represent. Development of drip irrigation (6) dates back to 1869. Initial systems were developed for greenhouse potted plants. Later these systems were extended to row crops. Several of the currently recognized advantages of drip irrigation (6) include efficient water use (minimum direct losses from evaporation, inhibited weed growth, no runoff), uniform and better quality crop, reduction in the development of pests and diseases, fertilization through irrigation and high application efficiency. Drip irrigation, like other irrigation methods, will not fit every agricultural crop, specific site, or objective. For crops with high plant densities requiring large amounts of drip line per land unit, drip irrigation may not be economical. Drip irrigation is an acceptable system of irrigating many crops; yet, it should not be expected to replace other irrigation methods.

The crop water requirements under drip irrigation may be different from those under conventional methods (6). Most methods of estimating water requirements presently utilized provide estimates of evapotranspiration. The evaporation of water from the soil surface is implicitly related to the method of irrigation application and irrigation scheduling.

\footnotetext{
${ }^{1}$ Manuscript submitted to Editorial Board, August 5, 1981.

${ }^{2}$ Assistant Agricultural Engineer and Agricultural Engineer, respectively, Agricultural Experiment Station, Mayagües Campus, University of Puerto Rico, Rio Piedras, P.R.
} 
Direct measurement of crop transpiration under drip irrigation has not been conducted for many crops. To schedule an irrigation correctly, the amount of soil moisture available to a crop and the water use by that crop must be quantified (7). Both timeliness and amount of water affect irrigation efficiency. However, timing has the greatest effect on crop yield and quality. Studies relating to stress during certain stages of growth and plant development support this $(6,7)$. Only two pieces of information are necessary to schedule irrigation: the allowable depletion level at which the effective root zone needs to be refilled and the periodic monitoring of the soil profile to determine if a recharge is needed (7). Tensiometers, because of their simplicity, availability and the lower range, are well adapted to drip irrigation work (6).

Splittstoesser (11) indicated that the cucumber plant stops growing if adequate water is not available. Heslip (4) reported that cucumber yield was increased because of higher soil temperature from plastic mulching. This condition hastened seedling emergence and increased plant vigor $(12,13)$. Other workers (1 to 5,8 to 13$)$ have also reported increased cucumber yield in plastic-mulched plots.

A study to determine the possibility of using drip irrigation for cucumber production was conducted at the Fortuna Substation, located in the semiarid southern coast of Puerto Rico. The soil belongs to the San Anton series with a $\mathrm{pH}$ of 7.9. The conductivity of the soil solution is $0.40 \mathrm{mmhos}$ per $\mathrm{cm}$. Maximum, minimum and average temperatures during the cucumber growing period were $32.8,16.7$ and $24.8^{\circ} \mathrm{C}$ respectively. The seasonal rainfall and Class A pan evaporation were $145.3 \mathrm{~mm}$ and $342 \mathrm{~mm}$, respectively.

The objectives of this study were to evaluate cucumber performance with silver coated black plastic, and estimate the drip irrigation requirements of the cucumber crop (variety Poinsett 76).

\section{MATERIALS AND METHODS}

A drip irrigation system was installed at the Fruits Substation, during March 1980. The system included a small electrically operated centrifugal pump, a 200-mesh screen filter, a pressure regulating valve, manifold accessories and main, submains and laterals. The water source was a well-fed reservoir. A volumetric metering valve monitored the water from the main to each submain. A submain was provided for each treatment. Laterals of dual chamber drip tubing with $0.76 \mathrm{~mm}$ orifices spaced $60 \mathrm{~cm}$ apart were placed $1.8 \mathrm{~m}$ apart to supply the water to the plants at 55-69 KPA (8-10 lb/in $\left.{ }^{2}\right)$. Layflat tubing was used for the main and submains. All irrigation materials were placed on the soil surface with orifices (emitters) facing upward.

Beds were shaped with a bed shaper on $1.8 \mathrm{~m}$ spacing. The 0.0015 
gauge silver coated black plastic mulch was manually placed over the desired beds. Holes were manually punched in the plastic at the position of the seedlings. Plot size was $9 \times 9 \mathrm{~m}$ ( 5 beds each $9 \mathrm{~m}$ long). Outer beds in each plot were left as border. The cucumbers were subjected to three water regimes (wet, moist and dry), with six replications in a randomized

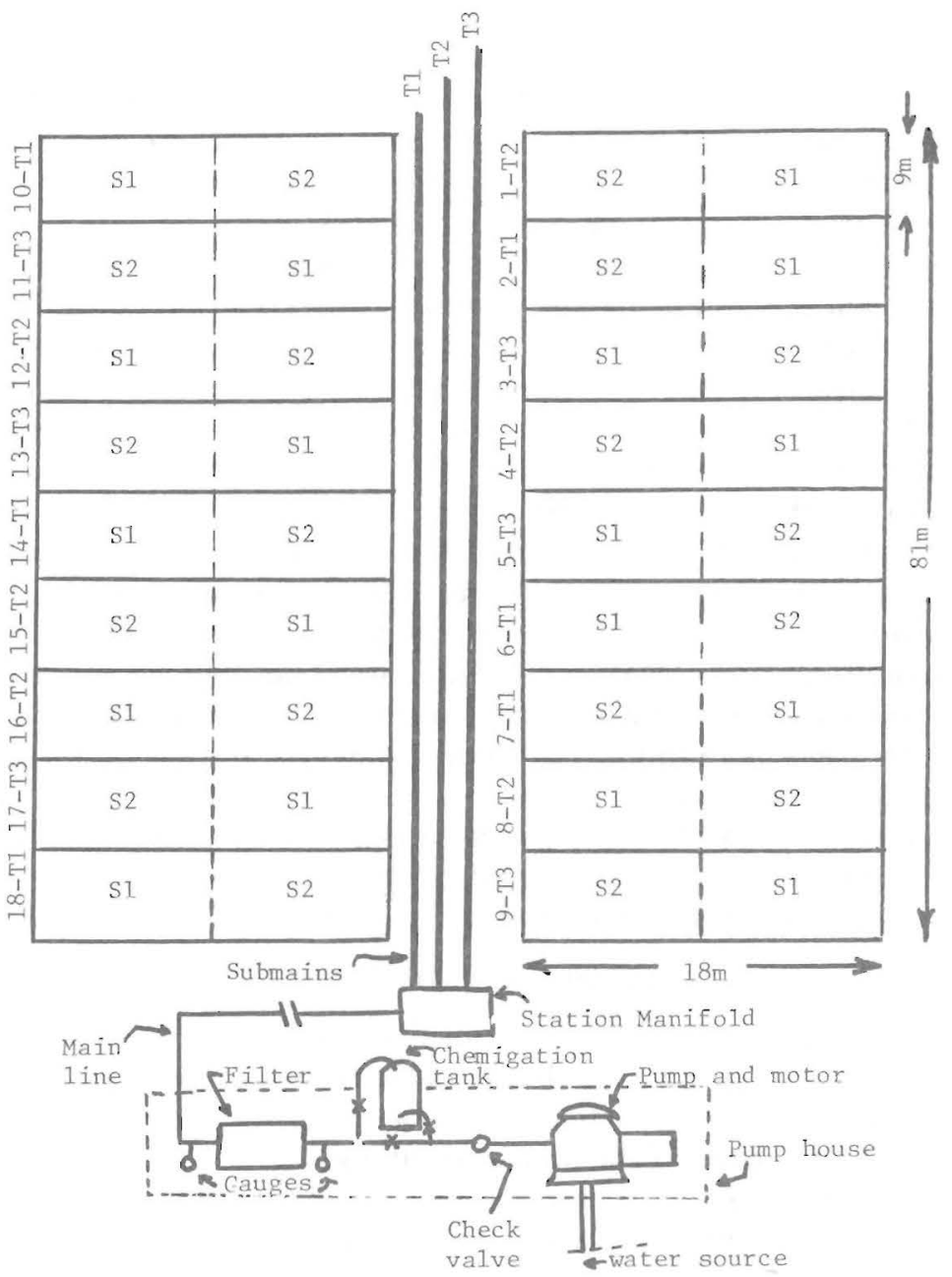

\footnotetext{
Main treatments Subtreatments

$\mathrm{T} 1=$ Wet $\mathrm{SI}=$ No plastic

P1ot size $=18 \times 9 \mathrm{~m}$

$\mathrm{T} 2=$ Moist $\mathrm{S} 2=$ Plastic

Bed size $=1.8 \mathrm{~m}$

$\mathrm{T} 3=$ Dry
}

FIG. 1.-Field layout for cucumber performance under trickle irrigation. 
split-plot block design as shown in figure 1. The split-plots were used to evaluate the effect of silver coated plastic mulch on cucumber yield.

Cucumber seeds (variety Poinsett 76) were sown March 31, 1980 at the rate of four seeds per hill on both sides of the dual chamber drip line in a zig-zag pattern at a distance of $15 \mathrm{~cm}$ from the drip line. The hill spacing was $60 \mathrm{~cm}$ down the row.

Water application rates were based on readings of tensiometers 15,30 and $45 \mathrm{~cm}$ below the soil surface to control the irrigation scheduling for the wet, moist and dry treatments. The tensiometers were installed according to "Tensiometer installation guide by Irrometer Company, Inc. ${ }^{3}$, Riverside CA". Irrigation was applied when the soil moisture tension, as measured by the tensiometers, was 45 cbars. Irrigation was terminated when the moisture tension dropped to 15 cbars.

The cucumbers were manually picked on $43,46,49,52,57$ and 60th julian day ${ }^{4}$. The last picking was on May 30, 1980. The fruit performance data included average fruit weight, volume and density. Archimedes principle was used to determine the average fruit volume.

\section{RESULTS AND DISCUSSION}

Total water volume applied during the growing period per emitter was 116.6, 90.3 and 71.3 liters for the wet, moist and dry treatments, respectively; and per plant, water applications were 14.6, 11.3 and 8.9 liters for wet, moist and dry treatments, respectively. Average daily water application per emitter was $1.9,1.5$ and 1.2 liters and $0.24,0.19$ and 0.15 liters per plant for the wet, moist and dry treatments, respectively. Seasonal water applications per hectare was $1.08,0.84$ and 0.66 million liters for the wet, moist and dry treatments, respectively, equivalent to $10.8,8.4$ and $6.6 \mathrm{~cm}$-hectare for the wet, moist and dry treatments, respectively. Sixty-seven percent of the water was applied during fruit formation.

Table 1 shows the average volume, weight and bulk density in six pickings of the cucumbers grown with mulch and without mulch under the wet, moist and dry treatments. In the non-mulch plots, average volume per fruit and weight per fruit were maximum in the fifth picking and average density per fruit was maximum in the third picking. With mulching, average volume per fruit and weight per fruit were maximum for first picking in the wet and moist treatments and in the fifth picking of the dry treatment. Average fruit density was maximum in the fifth picking. The minima were observed in the sixth picking in all treatments and subtreatments.

\footnotetext{
${ }^{3}$ Trade names are used only for identification purposes and do not imply preference for this material by the Agricultural Experiment Station.

${ }^{4}$ Julian day is a count of number of days after planting. Date of planting is zero julian day.
} 
Table 2 shows percentage distribution of the yield for each picking in each treatment. The yield was highest in the fifth picking and lowest in the sixth. Overall distribution of total yield was 11.7, 11.9, 12.6, 23.4, 31.7 and $9.0 \%$ in the first through sixth picking, respectively.

Table 3 shows the effects of the plestic mulch and of the varying water application rates on cucumber yield. The average total yields were 39.5 and 41.3 tons per hectare (17.1 and 17.9 tons per cuerda) ${ }^{5}$ with no mulch and with mulch, respectively. With mulch, the average yield for the moist

TABLE 1.-Fruit performance of cucumbers under drip irrigation. Date of planting: March 31, 1980. Date of last picking: May 30, 1980

\begin{tabular}{|c|c|c|c|c|c|c|}
\hline \multirow{3}{*}{ Fruit picking on days } & \multicolumn{6}{|c|}{ Fruit characteristics } \\
\hline & \multicolumn{2}{|c|}{$\begin{array}{l}\text { Average fruit volume, } \\
\qquad \mathrm{cm}^{3}\end{array}$} & \multicolumn{2}{|c|}{ Average fruit weight, $g$} & \multicolumn{2}{|c|}{$\begin{array}{l}\text { Average fruit density, g. } \\
\qquad \mathrm{cm}-3\end{array}$} \\
\hline & $\mathrm{P}^{1}$ & $\mathrm{NP}^{1}$ & $\mathrm{P}$ & NP & $\mathrm{P}$ & NP \\
\hline \multicolumn{7}{|c|}{$T 1=W e t$} \\
\hline 43 & 317 & 298 & 300 & 280 & 0.930 & 0.952 \\
\hline 46 & 256 & 256 & 240 & 240 & 0.938 & 0.948 \\
\hline 49 & 259 & 243 & 248 & 232 & 0.955 & 0.956 \\
\hline 52 & 253 & 253 & 238 & 240 & 0.940 & 0.947 \\
\hline 57 & 306 & 311 & 286 & 291 & 0.934 & 0.936 \\
\hline 60 & 176 & 173 & 153 & 161 & 0.917 & 0.880 \\
\hline \multicolumn{7}{|c|}{$T 2=$ Moist } \\
\hline 43 & 303 & 291 & 280 & 270 & 0.925 & 0.916 \\
\hline 46 & 286 & 290 & 267 & 250 & 0.915 & 0.939 \\
\hline 49 & 266 & 255 & 252 & 241 & 0.945 & 0.948 \\
\hline 52 & 247 & 238 & 270 & 224 & 0.935 & 0.944 \\
\hline 57 & 285 & 307 & 159 & 285 & 0.952 & 0.931 \\
\hline 60 & 179 & 176 & & 161 & 0.901 & 0.903 \\
\hline \multicolumn{7}{|c|}{$T 3=D r y$} \\
\hline 43 & 296 & 283 & 270 & 260 & 0.925 & 0.931 \\
\hline 46 & 269 & 263 & 253 & 243 & 0.943 & 0.913 \\
\hline 49 & 266 & 248 & 254 & 240 & 0.966 & 0.956 \\
\hline 52 & 251 & 236 & 236 & 222 & 0.939 & 0.942 \\
\hline 57 & 305 & 287 & 285 & 272 & 0.933 & 0.950 \\
\hline 60 & 188 & 180 & 160 & 171 & 0.912 & 0.892 \\
\hline
\end{tabular}

${ }^{1} \mathrm{P}=$ Plastic mulch; $\mathrm{NP}=$ No plastic mulch. Average of six observations.

treatment was 45.5 tons per ha (19.7 tons per cuerda) compared to 39.5 and 38.9 tons per ha for wet and dry treatments. In the non-mulched plots, the average yield for the moist treatment was 40.9 tons per ha (17.7 tons per cuerda) compared to 38.2 and 39.1 tons per ha for the wet and dry treatments. Although in general plastic mulching had no significant influence on the yield, and the differences between the yields of the corresponding moisture level treatments in the non-mulched plots were

${ }^{5}$ One cuerda is equivalent to 0.9712 acre; 0.39 ha. 
not significant, the crop yield under the moist treatment in the mulched plots was significantly greater at the $5 \%$ level than the yields under the wet and dry treatments. This may be due to the fact that under mulching the moist treatment was capable of furnishing an adequate supply of water to the plant system while maintaining adequate soil-air-plant relationships.

TABLE 2.-Percentage distribution of cucumber yield for each picking

\begin{tabular}{|c|c|c|c|c|c|c|}
\hline \multirow{3}{*}{ Treatment } & \multicolumn{6}{|c|}{ Percent of total yield } \\
\hline & \multicolumn{6}{|c|}{ Julian day } \\
\hline & 43 & 46 & 49 & 52 & 57 & 60 \\
\hline \multicolumn{7}{|c|}{ Plastic mulch $(P)$} \\
\hline $\mathrm{T} 1=\mathrm{Wet}$ & 10.8 & 12.5 & 12.6 & 23.1 & 31.9 & 9.1 \\
\hline $\mathrm{T} 2=$ Moist & 12.8 & 13.2 & 12.7 & 22.6 & 30.1 & 8.6 \\
\hline $\mathrm{T} 3=$ Dry & 12.7 & 11.7 & 11.8 & 24.4 & 29.7 & 9.7 \\
\hline Average & 12.1 & 12.5 & 12.4 & 23.4 & 30.6 & 9.1 \\
\hline \multicolumn{7}{|c|}{ Without plastic mulch (NP) } \\
\hline $\mathrm{T} 1=\mathrm{Wet}$ & 11.2 & 12.4 & 11.9 & 22.3 & 34.0 & 8.2 \\
\hline $\mathrm{T} 2=$ Moist & 11.3 & 10.7 & 13.4 & 23.6 & 32.8 & 8.2 \\
\hline $\mathrm{T} 3=$ Dry & 11.3 & 10.4 & 12.7 & 24.2 & 31.3 & 10.1 \\
\hline Average & 11.3 & 11.2 & 12.7 & 23.4 & 32.7 & 8.8 \\
\hline Overall Average & 11.7 & 11.9 & 12.6 & 23.4 & 31.7 & 9.0 \\
\hline
\end{tabular}

TABLE 3.-Effect of plastic mulch and varying water application rates on cucumber yield (var. Poinsett 76) grown under drip irrigation. Date of planting: March 31, 1980. Date of last picking: May 30, 1980

\begin{tabular}{|c|c|c|c|c|}
\hline \multirow{2}{*}{ Treatment } & \multicolumn{2}{|c|}{ Seasonal water application } & \multicolumn{2}{|c|}{ Cucumber yield } \\
\hline & Liters/plant & cm-ha & Metric tons/ha & Tons/cuerda \\
\hline \multicolumn{5}{|c|}{ Plastic mulch $(P)$} \\
\hline $\mathrm{T} 1=\mathrm{Wet}$ & 14.6 & 10.8 & $39.5 \mathrm{a}^{1}$ & 17.1 \\
\hline $\mathrm{T} 2=$ Moist & 11.3 & 8.4 & $45.5 b$ & 19.7 \\
\hline $\mathrm{T} 3=$ Dry & 8.9 & 6.6 & $38.9 \mathrm{a}$ & 16.9 \\
\hline Average & & & 41.3 & 17.9 \\
\hline \multicolumn{5}{|c|}{ No plastic mulch (NP) } \\
\hline $\mathrm{T} 1=\mathrm{Wet}$ & 14.6 & 10.8 & $38.2 \mathrm{a}$ & 16.6 \\
\hline $\mathrm{T} 2=$ Moist & 11.3 & 8.4 & $40.9 b$ & 17.7 \\
\hline T3 = Dry & 8.9 & 6.6 & $39.1 b$ & 16.9 \\
\hline Average & & & 39.5 & 17.1 \\
\hline
\end{tabular}

1. Means followed by the same letter do not differ at the $5 \%$ probability level.

\section{RESUMEN}

En marzo de 1980 se instaló en la Subestación de Fortuna un sistema de riego por goteo de baja presión para evaluar los requerimientos de riego para rendimientos máximos de pepinillo (variedad Poinsett 76), y para evaluar los efectos de la cubierta plástica negra con revestimiento 
plateado en el desarrollo de la cosecha. Las tasas de aplicación de agua se basaron en las lecturas de tensiómetros instalados a 15, 30 y $45 \mathrm{~cm}$ de profundidad en los tratamientos "mojado, húmedo y seco". Bajo cubierta plástica, el tratamiento "mojado" sobrepasó significativamente al $5 \%$ de significancia el rendimiento de los tratamientos "húmedo y seco". Los requerimientos medios de riego por goteo fueron $10.8,8.4$ y $6.6 \mathrm{~cm}$ ha para los tratamientos "mojado, húmedo y seco", respectivamente. Los datos de la evaluación de la cosecha incluyeron volumen medio, peso medio y densidad media de las frutas.

\section{LITERATURE CITED}

1. Blackhurst, H. T., 1962. Commercial use of black plastic mulch, Proc. Nat. Agr. Plast. Conf. 3:27.

2. Geraldson, C. M., 1962. Growing tomatoes and cucumbers with high analysis fertilizer and plastic mulch, Proc. Fla. State Hort. Soc. 75:253-60.

3. Hall, B. J., 1966. Polyethylene mulches in tomato and cucumber row covers, Proc. Nat. Agric. Plasti. Conf., 7:56-63.

4. Heslip, R. P., 1959. The influence of mulching on several vegetable crops with special references to black polyethylene, MS Thesis, Mich. State Univ. Reported from reference \#5.

5. Hopen, H. J. and N. F. Oebkar, 1976. Vegetable crop responses to synthetic mulchesan annotated bibliography. NAPA Technical Bulletin 1, National Agricultural Plastics Association.

6. Jensen, M. E., 1980. Design and Operation of Farm Irrigation Systems. ASAE Monograph No. 3, Am. Soc. Agric. Eng. Pages 663-713.

7. McSay, A. E. and F. D. Moore III., 1980. A model for scheduling lettuce irrigation. Dep. Hort., Colo. State Univ., Fort Collins, Colo.

8. Nettles, V. F., 1963. Planting and mulch studies with cucurbits. Proc. Fla. State Hort. Soc., 76:178-82.

9. Oebker, N. F. and J. W. Courter, 1960. Growers try paper mulch, Am. Veg. Grower, 8 (5):18-9.

10. Oyer, E. B., R. C. Herner and L. H. Aung, 1963. Interacting effects of plastic mulch, variety and date of planting on the yield of cucumbers, Proc. Nat. Agric. Plastic. Conf. 4:74-7.

11. Splittstoesser, W. F., 1979. Vegetable Growing Handbook. The AVI Pub. Co., Connecticut. Pages 194-96.

12. Tompkins, D. R. and R. L. Gabrielson, 1966. Influence of petroleum mulch and chemical treatments on pickling cucumber yields, West. Reg. Am. Soc. Hort. Sci. Abst.:6.

13. Tompkins, D. R., R. L. Gabrielson, and W. A. Haglund, 1967. Growth and production of pickling cucumbers as influenced by petroleum mulch and chemical treatments at planting. Proc. Am. Soc. Hort. Sci., 91:331-38. 